\title{
WIRE BASKETS-CURRENT PRODUCTS AND THEIR HANDLING AT PLANTING
}

\author{
by Bonnie Appleton ${ }^{1}$ and Scharlene A. Floyd ${ }^{2}$
}

\begin{abstract}
When field-dug, balled-and-burlapped trees are planted to the landscape, several options exist relative to wire basket modification or alteration. New wire basket alteration research has been initiated due to considerable controversy that surrounds some of the alteration options, and to limited prior research specifically addressing this issue. To guide this research, and to determine what currently occurs in the tree care industry, surveys of manufacturers of wire baskets, and of landscape contractors and arborists who plant trees, were conducted. Summaries of those surveys are presented.

Key Words. Balled-and-burlapped; galvanized; hydraulic diggers; machine-dug; mechanical harvest; nongalvanized; nursery production; root protection; transplanting.
\end{abstract}

In a chronology of the U.S. nursery industry, 1956 is listed as the year hydraulic tree diggers were introduced (Davidson et al. 1988). The authors stated that mechanical harvesting "revolutionized digging plants in nurseries." Prior to mechanical harvest, field-grown trees were dug by hand and generally handled either bare root or with their root balls wrapped in burlap and drum laced with string or rope.

Mechanical harvesting creates considerable savings in time and labor over hand digging. It allows for the harvest of trees grown in sandier soils, where hand digging is generally impossible because root balls break apart. In addition, larger-caliper trees, which generally are not practical to dig by hand, can be harvested. Nurserymen believe that wire baskets, compared to rope-laced balls, drastically reduce the number of damage claims, increase tree survival chances in the landscape, and create an overall more appealing and marketable product (Desmarteau 2002).

\section{WIRE BASKET EVOLUTION}

To accommodate mechanical harvesting, an appropriate receptacle had to be developed to hold root balls extracted with hydraulic diggers. The question of the origin of wire baskets was posed to representatives of two major wire basket manufacturing companies-Peter Braun, president of Braun Horticulture, Inc., Ontario, Canada, and Mark Frost, sales representative for Cherokee Manufacturing, South St. Paul, Minnesota (personal communications). Frost stated that, initially, crude versions of currently manufactured wire baskets were made by local "job shops" to fit hydraulic diggers as the machines were developed. Braun stated that the first real introduction of wire baskets was approximately 25 years ago by Remke Industries, Inc., Wheeling, Illinois. Baskets were designed around both the hydraulic digger blade configurations and the configurations of roots of different species of trees.

Several configurations of wire baskets are currently manufactured. Cone-shaped (pointed) root balls and baskets with a 30 degree angle are recommended for rocky or lighter (sandier) soils to help maintain root ball integrity. Root balls and baskets with lesser angles (truncated), which produce rounded and flat-bottomed balls, work well for heavier or tighter (more clayey) soils. Frost stated that "Neither one is better than the other. Soil type should dictate the shape or angle of the mechanical harvester and basket that is used."

\section{THE WIRE BASKET CONTROVERSY}

Most people in nursery production, landscape contracting, and urban tree care do not dispute that wire baskets are invaluable for protecting tree root balls during harvest, shipping, and storage, and during transport to and movement around landscape sites (positioning, lowering into the hole, etc.). What is disputed, however, is whether wire baskets pose any significant danger if left unaltered or modified at planting. The question of alteration applies not only to conventionally balled-and burlapped-trees in wire baskets, but also to trees whose wire basket-encased root balls have been containerized, with additional substrate often obscuring the wire baskets.

Many nurseries say removal or alteration is unnecessary. They fear that removal or alteration will result in root ball damage or tree stability problems and consequently often won't guarantee tree survival if basket removal or alteration occurs. However, many planting specifications mandate either partial or total basket removal, or some other form of basket alteration. This required removal or alteration places landscape contractors in a no-win situation between nursery nonremoval policies and specification removal/ alteration requirements.

At the "other end" of a tree's life, many arborists who remove trees frequently point to unaltered baskets as "tree killers." They do not understand why removal or alteration 
is not required of landscape contractors; therefore, a very negative view of nursery production and landscape installation practices exists within much of the arboricultural community.

\section{POTENTIAL WIRE BASKet DAMAGE TO TREE ROOTS}

Many anecdotal reports exist that attribute tree stress, decline, or death to wire baskets left intact when balled-andburlapped trees are planted. Requiring alteration or removal supposedly prevents detrimental cutting or girdling of tree roots or stems by the basket wire. This implied damage is never immediate but is said to generally occur years after installation, when burlap may have deteriorated but wire baskets are still intact. Those reporting implied damage say they generally see the damage when root collar excavations are performed or when tree removal becomes necessary.

The first wire baskets used were made from nongalvanized steel, and it was assumed that within a few years they would rust away and pose no potential hazards. According to Watson and Himelick (1997), wire baskets can last up to 30 years below ground. This article's senior author excavated numerous wire baskets during spring and summer 2003. Many of the baskets, known to be in the ground from 15 to 18 years, were still completely intact and, though corroded, the basket wire was very difficult to break.

Lumis (1990) reported that wire strength diminishes very slowly below ground. Tensile strength of 9-gauge, galvanized and nongalvanized wire was tested on baskets that had been planted for 4 years. Over the $48 \mathrm{~cm}$ (19.2 in.) depth of the baskets, tensile strength of the galvanized wire, which transitioned from slightly discolored to slightly corroded with depth, decreased only $5 \%$. Nongalvanized wire, which was moderately corroded over its entire depth, decreased in tensile strength by only 3\%. Lumis stated that these, and similar tests performed on wire that had been in soil for longer time periods, indicated that significant corrosion does not occur rapidly as a result of either less oxygen or more moisture at various soil depths.

While Carpenter (1987) reported that many thousands of trees had been planted in wire baskets with very few reports of problems, Watson and Himelick (1997) stated that tops of buttress or flare roots generally grow into the upper horizontal basket wires, causing partial girdling of roots and restricting vascular flow (xylem water and nutrient transport up, and phloem carbohydrate transport down). Whitcomb (1987) reported root restrictions and injury to roots of several trees planted in painted, but not galvanized, wire baskets that had been in the ground for 6 years and that showed little signs of deterioration except near the soil surface.

Research to date addressing the vascular flow part of this controversy has been limited. In 1988, Lumis and Struger reported that large structural roots of approximately 11 - year-old golden willow (Salix alba 'Trista') had deeply embedded wire beyond which, after 1 to 2 years, a complete union of vascular tissue had formed despite initial infolding of periderm tissue. Lumis (1990) reported the same observations with other tree species, but noted that these observations did not confirm the anatomical or functional integrity of the vascular tissue. These observations were in contrast to those of Feucht (1986), who stated that root vascular tissue does not rejoin after growing around wire.

In research with 2-year-old green ash (Fraxinus pennsylvanica) and hackberry (Celtis occidentalis) and 2-yearold whips of a hybrid poplar (Populus angulata $\times$ plantierensis), Goodwin and Lumis (1992) reported none of the trees whose roots were girdled with wire had grown any less than those with nongirdled roots after 6 months. They did report, however, that full girdling significantly reduced foliage dry weight in ash. The rate of transpiration in ash and hackberry was significantly reduced, and a gradient of water potential was observed across the wire girdle in the xylem. Root tissue carbohydrate level, and its distribution in relation to the wire, was slightly influenced by girdling in all three species. They concluded that although this research did not answer the question of whether wire baskets should be removed at planting, they felt that compared to the stresses that occur due to significant root loss at harvest for field-dug trees, the effect of roots growing over wire baskets would be limited.

Though root tissue may eventually grow around the wires and graft together on the other side, this reestablishment of unrestricted vascular transport may take several years. During the time that restricted vascular transport exists, the tree may become stressed, causing other problems to develop, including insects and diseases, tree instability, reduced shoot growth, and decline and death (Sellers 1983; Lumis 1990; Watson and Himelick 1997).

Even if movement of materials in the vascular tissues is not impaired, basket wire may cause potential problems with anchoring stability. The senior author has observed Norway maples (Acer platanoides) that appeared to have blown over due to flare root girdling. A personal communication to Harris et al. (2004) reported that cottonwood (Populus deltoides), ash (Fraxinus spp.), and pine (Pinus spp.) trees blown over by tornado-like wind appeared to have their roots break at or just outside wire baskets left intact at planting 7 to 10 years prior to the root breakage.

\section{POTENTIAL WIRE BASKeT DAMAGE TO PEOPLE AND EQUIPMENT}

Whether or not wire baskets pose a hazard to tree roots, they are real hazards to people and equipment (lawn mowers, rakes, etc.). Entire sections and broken pieces of wire baskets frequently protrude above ground, especially with the fairly common practice of planting trees shallow in poorly drained sites or in heavier soils. These aboveground 
wire sections and pieces can be especially hazardous to children and pets playing in their vicinity. In addition, when the senior author questioned arborists who grind out tree stumps as part of tree removal, nearly all questioned had experienced, and many had been injured by, flying metal when wire baskets were contacted by the grinding equipment.

\section{LITERATURE AND INTERNET SEARCHES}

To determine what is most commonly recommended relative to wire basket handling at planting, several surveys were conducted in 2002 and 2003. Harris et al. (2004) stated that wire baskets are seldom removed at planting time, although his reference book, and four other major arboricultural references, all suggest that at least part of the wire be removed (Table 1). Watson and Himelick (1997) stated that "the reasons given by contractors for not removing the wrappings (or the critical portions of them) are not usually horticultural. The extra time it takes to remove them may increase the cost of planting, and it may be more difficult to straighten the tree without breaking the root ball if it begins to lean after planting. Thoroughly stabilizing the lower part of the root ball at planting will keep firm root balls from shifting, and they will usually not have to be straightened later."

In a search of the Internet, a majority of the first 50 sites, ranging from cooperative extension publications to magazine articles to recommendations by garden centers, nurseries, and landscape contracting firms, acknowledged the benefits of wire baskets relative to harvesting and handling. While a majority also recommended some form of wire basket alteration or removal at planting, those sites that did not were almost exclusively wholesale nurseries growing field stock.

\section{WIRE BASKET MANUFACTURER SURVEY}

To gain a perspective of the types of wire baskets used in the United States, and to determine the short- and long-term goals that manufacturers of wire baskets have when designing their products, surveys were sent to the eight wire basket manufacturers that the authors could identify as selling wire baskets to nurseries that harvest field-grown trees. Six manufacturers (representing the bulk of the wire baskets used in the United States) responded. The following is a summary of the information collected from the surveys:

- Basket configuration-Four companies manufacture mainly cone-shaped baskets, whereas two companies manufacture mainly truncated or flat-bottomed baskets.

- Basket wire type-Three companies manufacture mainly galvanized baskets (zinc-coated steel), two make both galvanized and nongalvanized baskets, and one makes only nongalvanized baskets. The trend is toward mainly galvanized baskets so that nurseries can store or stockpile baskets outside without basket corrosion (rusting) or deterioration prior to use.

Table 1. Wire basket handling recommendations of major arboricultural references.

\begin{tabular}{|c|c|c|c|}
\hline Reference & Author & $\begin{array}{l}\text { Publication } \\
\text { date }\end{array}$ & Recommendation \\
\hline Arboriculture & $\begin{array}{l}\text { Harris, Clark, } \\
\text { and Matheny }\end{array}$ & 2004 (4th edition) & $\begin{array}{l}\text { "Removing the wire from around the top } \\
200 \text { to } 300 \mathrm{~mm} \text { ( } 8 \text { to } 12 \mathrm{in} \text {.) of the root ball } \\
\text { (depending on size) would be wise for most } \\
\text { landscape trees." "Remove the wire from } \\
\text { around the top of the root ball ..." }\end{array}$ \\
\hline $\begin{array}{l}\text { Arborist's Certification } \\
\text { Study Guide }\end{array}$ & Lilly & 2001 & $\begin{array}{l}\text { "Although it may be impractical to remove } \\
\text { the entire basket, it is preferable to cut away } \\
\text { as much of the wire as possible, once the } \\
\text { tree is in the planting pit and the ball is stabilized." }\end{array}$ \\
\hline Pirone's Tree Maintenance & $\begin{array}{l}\text { Hartman, Pirone, } \\
\text { and Sall }\end{array}$ & 2000 (7th edition) & $\begin{array}{l}\text { "Wire baskets, essential to lowering the tree } \\
\text { into the hole, are no longer needed, and } \\
\text { wire strands should be cut with a bolt cutter } \\
\text { as far down the sides of the ball as possible." }\end{array}$ \\
\hline $\begin{array}{l}\text { Principles and Practices } \\
\text { of Planting Trees and Shrubs }\end{array}$ & Watson and Himelick & 1997 & $\begin{array}{l}\text { "All potentially damaging portions of the } \\
\text { wire basket should be removed at planting } \\
\text { time." "To prevent future problems, cut off } \\
\text { the top half of the basket before backfilling." }\end{array}$ \\
\hline $\begin{array}{l}\text { Trees for Urban and } \\
\text { Suburban Landscapes }\end{array}$ & Gilman & 1997 & $\begin{array}{l}\text { "Remove the top portion of the wire basket } \\
\text { after root ball is in place." }\end{array}$ \\
\hline
\end{tabular}


- Wire strand continuity-Only one company manufactures its baskets from one continuous strand of wire, while the remainder manufacture their baskets by welding wire strands.

- Short-term product design goals-Four companies indicated ease of harvest for the grower, one indicated cost, one indicated easier landscape installation, and one indicated root ball security (one company gave two responses) as their short-term product design goal.

- Long-term product design goals-Four companies indicated root ball protection, and two indicated stabilization of the root ball as their long-term product design goal. In addition, two that manufacture mainly galvanized baskets indicated persistence in the soil as a goal.

- Manufacturer installation recommendationsThree companies recommend removing or bending down the top basket loops (ears) at planting or 1 year thereafter. One company recommends removing the bottom of the basket, and two make no recommendations at all relative to basket handling at planting.

\section{PRACTITIONER SURVEY}

To gain a perspective of how wire baskets are actually handled at planting, a practitioner survey was developed and distributed at several U.S. mid-Atlantic region field days and conferences, and via regional and national trade publications (Tree Care Industry, NMPro, Groundworks, Newsletter of the Virginia Nursery and Landscape Association, SCA Today, The Log) during 2002 and 2003. The following is a summary of over 300 responses received primarily from landscape contractors and arborists:

- Basket configuration-A majority of practitioners had no preference regarding basket configuration, but if a preference was listed it was generally for truncated or flat-bottomed baskets rather than cone baskets due to easier handling.

- Basket wire type-A majority of practitioners preferred that baskets be nongalvanized.

- Wire strand continuity-A majority of practitioners did not care whether baskets were manufactured from a continuous strand of wire or from welded strands.

- Installation practices-A majority of practitioners alter wire baskets in some fashion at planting. Most remove the top portion (loops or ears, and many also remove the top horizontal round of wire), while a smaller number split the basket vertically and lay it down into the planting hole, or remove the basket entirely.

Additional surveys, primarily of landscape designers and architects, are planned for the future.

\section{WIRE BASKET HANDLING RESEARCH}

Due to a manufacturer trend to produce mainly galvanized baskets that will potentially last longer in the soil after planting, and because of the response from $50 \%$ of surveyed practitioners that they'd seen what was perceived as root and/or stem damage as a result of leaving wire baskets intact at planting, long-term research was started in March 2003. The objective of this research is to try to determine whether the top sections of wire baskets can potentially damage surface buttress or flare roots. The research is being conducted at Virginia Tech's Hampton Roads Agricultural Research and Extension Center in Virginia Beach. Four treatments, based on current industry practices, were used: no wire basket removal or alteration; complete wire basket removal; removal of the top loops and horizontal round of wire; and splitting the wire basket vertically and laying the two halves down into the planting hole. These treatments, replicated five times in a randomized complete block design, were applied to two commonly used landscape trees-river birch (Betula nigra) and Bradford pear (Pyrus calleryana 'Bradford'). Roots of these trees will be exposed yearly using air-excavation equipment, and the growth of the roots relative to the treatments will be recorded.

\section{ALTERNATIVES TO WIRE BASKETS}

At present, no economically feasible alternative to wire baskets exists for field harvesting. Many nurseries have begun to grow larger-caliper trees in containers, in particular using square wood or plastic boxes whose sides are removed at planting time, or using the pot-in-pot production system (Appleton 1995).

In Europe, it has been reported that baskets made of supposedly breakable plastic, rather than of wire, are used (Gardner-Young 1981). However, a literature search did not provide any published reports of what effects the plastic has had on root growth.

For shrubs and small trees, some nurseries use an expandable wire basket made of thin-gauge, nongalvanized, loosely woven steel. Desmarteau (2002) reported that these baskets begin breaking down in soil a few weeks after planting and are completely disintegrated within 2 years. Whether these thinner wire baskets could be used for larger-caliper trees needs to be determined.

According to Smiley and Booth (2002), an easy way to avoid girdling roots with wire baskets is to use a basket that is one size smaller than the size of the harvested root ball. This practice, referred to in the nursery industry as "icecream balling" (personal communication), leaves the top 15 $\mathrm{cm}(6 \mathrm{in}$.) or so of the root ball above the top of the wire basket. Theoretically, this should be enough area left uncovered by wire baskets that no significant buttress root girdling can occur. 
A plastic container-the Plant \& Release ${ }^{\mathrm{TM}}$ — with sides that are removed once the root ball is positioned in the landscape hole, has recently been introduced by Maywood Evergreen, Marine on St. Croix, Minnesota. This new container, however, has not yet been field tested against wire baskets in an unbiased comparative study. Until such time as one of these options proves viable or becomes more commonly used, or conclusive results are reported from new research, the controversy over how to handle wire baskets at planting time will continue.

\section{LITERATURE CITED}

Appleton, B.L. 1995. Nursery production methods for improving tree roots-An update. J. Arboric. 21:265-270.

Carpenter, P.L. 1987. Are there long-term problems with wire baskets? Nat. Landsc. Assoc. Tech. Notes July/Aug.

Davidson, H., R. Mecklenburg, and C. Peterson. 1988. Nursery Management. Prentice Hall, Engleside Cliffs, NJ. 412 pp.

Desmarteau, R. 2002 Getting wired. Am. Nurseryman 195(4):53-54, 56

Fuecht, J.R. 1986. Wire baskets can be slow killers of trees. Am. Nurseryman 163(3):156-159.

Gardner-Young, J.W. 1981. A new method of planting trees and shrubs. Arboric. J. 5:45-48.

Gilman, E.F. 1997. Trees for Urban and Suburban Landscapes. Delmar Publishers, New York, NY. 662 pp.

Goodwin, C., and G. Lumis. 1992. Embedded wire in tree roots: Implications for tree growth and root function. J. Arboric.18:115-122.

Harris, F.W., J.R. Clark, and N.P. Matheny. 2004. Arboriculture: Integrated Management of Landscape Trees, Shrubs, and Vines (4th ed.). Prentice Hall, New York, NY. 578 pp.

Hartman, J.R., T.P. Pirone, and M.A. Sall. 2000. Pirone's Tree Maintenance (7th ed.). Oxford University Press, New York, NY. 545 pp.

Lilly, S.J. 2001. Arborists' Certification Study Guide. International Society of Arboriculture, Champaign, IL. $222 \mathrm{pp}$.

Lumis, G.P. 1990. Wire baskets: A further look. Am. Nurseryman 172(5):128-131.

Lumis, G.P., and S. A. Struger. 1988. Root tissue development around wire-basket transplant containers. HortScience 23:401.

Sellers, A.G. 1983. Tree roots and wire baskets, are they compatible? Ont. Shade Tree Council Newsl. 2:4.

Smiley, E.T., and D.C. Booth. 2002. Are nursery trees grown to self-destruct in the landscape? www.marshalltrees.com.

Watson, G.W., and E.B. Himelick. 1997. Principles and Practices of Planting Trees and Shrubs. International Society of Arboriculture, Champaign, IL. 199 pp.

Whitcomb, C.E. 1987. Establishment and Maintenance of Landscape Plants. Lacebark Publications, Stillwater, OK. $618 \mathrm{pp}$.
${ }^{1 *}$ Professor of Horticulture

${ }^{2}$ Graduate Student

Hampton Roads Agricultural Research and Extension Center

Virginia Polytechnic Institute and State University

1444 Diamond Springs Road

Virginia Beach, VA 23455, U.S.

*Corresponding author.

Résumé. Lorsque des arbres qui sont arrachés des champs et mis en motte (jute avec panier de broche) sont plantés dans les aménagements, plusieurs possibilités existent quant aux modifications ou aux altérations que peuvent subir les paniers de broches. Une nouvelle recherche sur l'altération des paniers de broches a été entreprise, et ce en raison de la controverse énorme qui concerne certaines des possibilités d'altérations et aussi pour limiter les priorités de recherche spécifiquement à cette problématique. Pour orienter cette recherche et pour déterminer qu'est-ce qui se passe dans l'industrie de l'entretien arboricole, des enquêtes ont été menées à la fois auprès des manufacturiers de paniers de broche et auprès des paysagistes ainsi que des arboriculteurs qui plantent des arbres. Des sommaires de ces résultats sont présentés.

Zusammenfassung. In Relation zur

Drahtkorbausbildung, bzw. in Alternative dazu, gibt es verschiedene Möglichkeiten, ballierte Bäume auszupflanzen. Wegen verschiedener Kontroversen wurde eine Untersuchung über eine neue Drahtkorbgestaltung initiiert, um einige Änderungsmodalitäten zu erörtern und die Forschung speziell auf dieses Thema einzugrenzen. Um diese Forschung zu leiten und zu begrenzen, was gegenwärtig in der Baumindustrie geschieht, wurden Umfragen sowohl bei Herstellern und auch bei Landschaftsbauern durchgeführt. Die Ergebnisse dieser Umfragen wurden hier präsentiert

Resumen. En el banqueo de los árboles para el trasplante, existen varias opciones con relación a la modificación o alteración de la malla de alambre para el arpillado. Se han iniciado nuevas investigaciones debido a la controversia generada por el uso de estos materiales. Con el propósito de guiar esta investigación y para determinar que está ocurriendo actualmente en la industria del cuidado de los árboles, se hicieron consultas tanto a manufacturadotes de mallas de alambre como a contratistas del paisaje y arboristas, que se dedican a la plantación árboles. Se presentan los resúmenes de estos estudios. 